Mr. J. Latham (finance member). To provide the means of maintaining contact between all people engaged on this research and formal facilities for the exchange of ideas, an Advisory Committee will be set up, and its terms of reference will include the discussion of progress in research in the medical, human and management fields, the suggestion of the lines on which new research projects might be fruitfully developed, and consideration of the ways in which the information gathered and the research findings might most profitably be disseminated and used.

\section{British Agricultural Delegation to visit the U.S.S.R.}

AT the invitation of the Government of the U.S.S.R. a British agricultural delegation is to visit that country; this invitation follows the recent visits to the United Kingdom of two agrieultural delegations from the U.S.S.R. The United Kingdom delegation will be led by Mr. G. R. H. Nugent, Joint Parliamentary Secretary to the Ministry of Agriculture, Fisheries and Food. The delegation will leave for the U.S.S.R. on September 25 and will return on October 9; its programme will include visits to the Agricultural Exhibition in Moscow, to farms and to agricultural research and experimental stations. In addition to Mr. Nugent, the delegation will include : Prof. H. G. Sanders, chief scientific adviser (agriculture) to the Ministry of Agriculture, Fisheries and Food; Dr. E. E. Cheesman, scientific adviser, Agricultural Research Council; Dr. H. P. Donald, director of the Agricultural Research Council's Animal Breeding Research Organization, Edinburgh; Sir Peter Greenwell, member of the Council of the Royal Agricultural Society of England ; Prof. D. S. Hendrie, principal of the West of Scotland Agricultural College ; Dr. P. S. Hudson, director of Commonwealth Bureau of Plant Breeding and Genetics, Cambridge; J. Mackie, chairman of the Scottish Committee of the National Institute of Agricultural Engineering; Dr. A. Muir, head of Soil Survey of England and Wales and head of the Pedology Department, Rothamsted Experimental Station; Dr. J. A. B. Smith, director of the Hannah Dairy Research Institute; Dr. A. W. Stableforth, director of Veterinary Laboratories, Ministry of Agriculture, Fisheries and Food; W. C. Tame, under-secretary, Ministry of Agriculture, Fisheries and Food; and representatives of trade unions associated with agriculture. The News Chronicle, which was host for one of the recent Russian delegations to Great Britain during part of its stay, has also been invited by the U.S.S.R. to send six representatives; this group will travel with the official delegation, but will probably follow a separate programme.

\section{The Cleanliness of the British Scene}

As the result of a summer of outstanding brightness and delight, in which many in Britain have been prompted to spend the maximum practicable amount of time in the open air, the matter of dreary and blackened buildings, rendered more dismal by the onset of rain, may have been well forgotten for the time. The hour is fast approaching when the issues to be put before Parliament in the Clean Air Bill will arouse the Press, and the attention of the public will be directed to its hoped-for progress through the House. The summer issue, therefore, of a journal that has grown attractive from the efforts of those who have been zealous in the development of smoke abatement is of particular interest at the present time; it is Smokeless Air (25, No. 94), the official organ of the Smoke Abatement Society. With the smoke and air pollution that has been the result of the growth of industrial activity in the British Isles, there now looms before us the problem of radioactive pollution associated with the development of atomic energy so necessary to assist our survival as an industrial community. There is a timely reprint in this journal of an address by Sir John Cockcroft, given to the Parliamentary and Scientific Committee on the subject of radioactive pollution (see Nature, May 21, p. 873), which is for the time being reassuring. It yet defines a problem which has been very prominent in the news in recent months.

The same issue of Smokeless Air also contains a racy contribution from the pen of a Frenchman, Roger Valvert, entitled "A Frenchman looks at Britain's Smoke". A succession of pert reflexions on the Englishman's robustness and toughness in enduring his apparently barbaric forms of heating almost commends the scepticism with which the Beaver Committee report on "Air Pollution" was received last year. We read of "smog, that cocktail of smoke and fog, typical of London and other great industrial centres". Again, "Coal is scarce. One must not waste it. If then this method of heating does not heat, it teaches the English to live in what Continentals would consider cold". Another pleasant gibe runs, "The Englishman to our mind is badly fed and heated, but he has his own flat, or more often house, redecorated every two years, and a well-kept garden. He has a bathroom even if it is arctic. To teach him efficient heating is, therefore, to risk a catastrophe". The author fires his parting shot by suggesting that it would not be a bad thing to observe how the truly sporting spirit helps, that typical characteristic of the Englishman. We shall see when the battle is joined in the coming months. The editor of Smokeless Air deftly puts in a final riposte by observing that, according to a municipal councillor, the air of Paris will soon be as poisonous as that of London, and he quotes chapter and verse.

\section{Colour in Foods}

THE Quartermaster Food and Container Institute in Chicago is an active centre for both fundamental and applied research in food technology. It is responsible for the specifications for foodstuffs supplied to the United States Army, and it maintains close relations with scientific workers in the universities, in industry and in other government departments. This co-operation is fostered through an Advisory Board established by the National Research Council and through various advisory committees, and during recent years a number of specialized conferences have been arranged jointly by the Institute and the Council. Several valuable reports of these meetings have already been published, the latest of these being on "Color in Foods", based on a symposium held in Chicago during November 3-4, 1953 (pp. 186 ; from the Quartermaster Food and Container Institute, 1819 West Pershing Road, Chicago 9 , Ill.; 1954 ; n.p.). The sixteen contributors discuss a wide range of problems, including the fundamental concepts of colour measurement, the psychological approach to colour preferences, and the nature and reactions of the carotenoids and other food pigments. Several of the papers are concerned directly or indirectly with instrumentation, and they reveal the progress that has been made during recent years in the design of equipment both for research 